\title{
Role of antileukotrienes in acute asthma exacerbations
}

Domenico Lorenzo Urso ${ }^{1}$, Daniele Vincenzo ${ }^{1}$, Lorenzo Formaro ${ }^{1}$, Ada Federico ${ }^{2}$, Giuseppe Urso ${ }^{3}$

Emergency Department, Vittorio Cosentino Hospital, Cariati M. (CS), Italy

Pharmacology Institute, Vittorio Cosentino Hospital, Cariati M. (CS), Italy

Doctor of Pharmacy, Cariati M. (CS), Italy

\section{Abstract}

Acute asthma exacerbations are one of the most frequent reasons to visit the emergency department or general practitioner. Although current standard treatments for acute asthma - including supplemental oxygen, short-acting $\beta_{2}$-agonists, systemic corticosteroids and anticholinergics - are quite effective in most patients, they are inadequate for rapid and sustained improvement in a significant proportion. The antileukotrienes, a relatively new class of drugs, have a role in the treatment of chronic asthma. Their relatively rapid onset of action after endovenous or oral administration and their additive effect to $\beta_{2}$-agonists led to the hypothesis that they might be of benefit in acute asthma. This review examines the efficacy of antileukotrienes in the treatment of acute asthma.

\section{Keywords}

Acute asthma; Antileukotrienes; Cysteinil-leukotrienes; Airways inflammation 


\section{Introduction}

Antileukotrienes are a relative new class of drugs for the treatment of asthma that either block leukotriene synthesis or antagonize the most relevant of their receptors (Figure 1). They include:

- 5-lipoxygenase (5-LO) inhibitors: zileuton;

- leukotrienes receptor antagonists (LTRAs) or cysteinyl leukotriene-1 (CysLT1) antagonists: montelukast, zafirlukast, and pranlukast.

Antileukotrienes have an established role in the management of chronic asthma [1-3]. Several studies in adults and children have reported increased levels of leukotrienes (LTs) in acute asthma that fall as the attack resolves [4]. The administration of a single dose of LTRAs causes a mild but significant bronchodilation in stable asthmatic patients, and this effect is additive with the bronchodilator effect of short-acting $\beta_{2}$-agonists [5]. The effect can be observed in less than 1 hour and persists up to 12-24 hours [6]. These studies have led to speculation that LTs have a significant role in the bronchospasm typical of an acute asthma attack. However there are few studies on the effect of antileukotrienes in acute asthma. This review aims at examining the effects of these

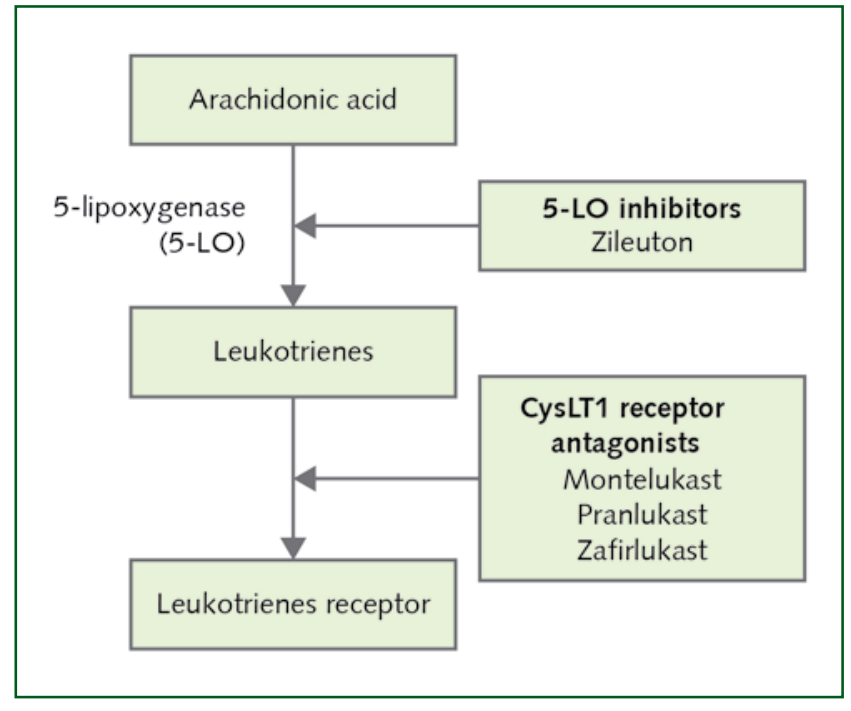

Figure 1. Mechanism of action of antileukotrienes drugs in acute asthma.

\section{Role of leukotrienes in acute asthma}

LTs, including cysteinil-LTs (LTC4, LTD4 and LTE4) and LTB4, are potent biological lipid mediators derived from arachidonic acid through the 5-lipoxygenase (5-LO) pathway (Figure 2) [7]. They produce bronchospasm, increase the degree of bronchial hyperresponsiveness, mucus production, and mucosal edema, and stimulate airway smooth muscle cell proliferation and eosinophil recruitment in the airways [6]. Specific pathways for the synthesis of cysteinil-LTs are present in several types of inflammatory cells and become activated during allergic airway inflammation [8]. Two subtypes of receptor for cysteinil-LTs (CysLT1 and CysLT2) have been identified [9]. Most of the effects of cysteinil-LTs relevant to the pathophysiology of asthma are mediated by activation of the CysLT1 receptor, which is expressed in different types of inflammatory and structural cells in the airways [8]. Increased amounts of cysteinil-LTs are found in the blood, sputum, and urine of asthmatic patients [10]. Cysteinil-LTs are the most potent endogenous bronchocostrictors, increase mucus secretion in isolated animal and human airways and increase microvascular permeability in the lungs in experimental animal models [11]. Cysteinil-LTs have the eosinophil chemotactic effect, but the mechanisms are not completely known [12]. Two LTB4 receptor subtypes have been identified: BLT1 and BLT2. LTB4 is a potent chemoattractant for neutrophils and might be functionally involved in asthma exacerbations. LTB4 may contribute to a reduction in airway calibre due to local edema and increasing secretion, although it has no bronchoconstrictor effect in healthy and asthmatic subjects $[11,12]$. 


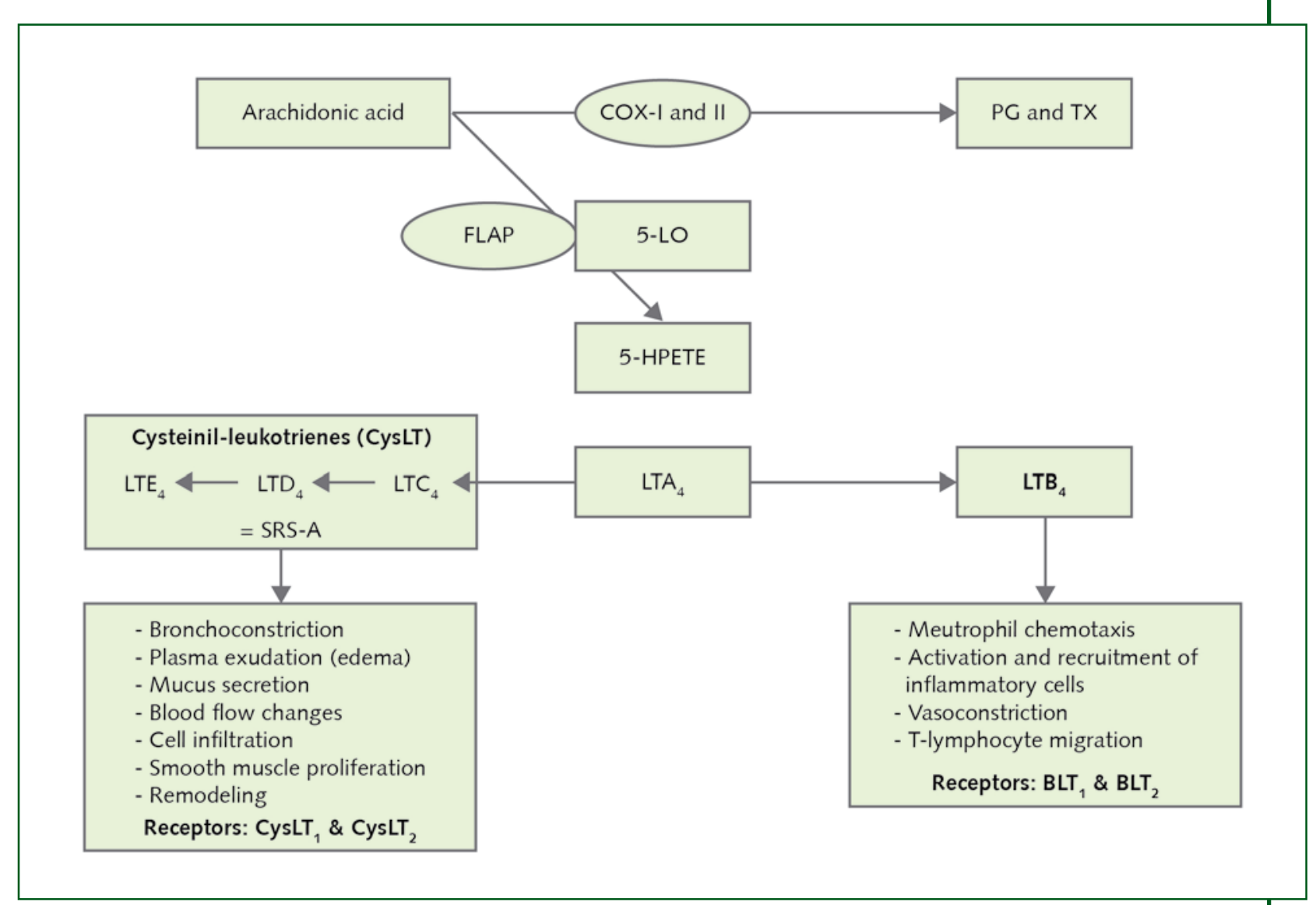

Figure 2. Transformations pathways of arachidonic acid and biological effects of leukotrienes and their receptors

5-LO = 5-lipoxygenase; COX = cyclooxygenase; FLAP = five lipoxygenase activating protein; LT = leukotrienes; $\mathrm{PG}=$ prostaglandins; $\mathrm{SRS}-\mathrm{A}=$ slow reacting substance of anaphylaxis; $\mathrm{TX}=$ thromboxane

\section{Acute asthma exacerbation}

An acute asthma exacerbation can be generally defined as acute or subacute episodes of progressively worsening shortness of breath, cough, wheezing, and chest tightness or some combination of these symptoms [2]. Treatment goals for acute asthma include correction of significant hypoxemia, rapid reversal of airflow obstruction, and reduction in the likelihood of recurrent severe airflow obstruction $[1,2]$. Oxygen, short-acting $\beta_{2}$-agonists, and systemic corticosteroids are the basis of management of acute asthma exacerbation. Treatment should be tailored to the severity of the exacerbations [1-3,13]. However, up to $30 \%$ of patients who present with acute asthma will fail to respond adequately to shortacting $\beta_{2}$-agonists [14] and benefit from systemic corticosteroids is not generally observed for 4-6 hours or longer [15]. Therefore there is a need for new treatment options that provide benefits beyond the current standard treatments.

\section{The potential benefits of antileukotrienes in acute asthma}

Antileukotrienes provide benefit in asthma by decreasing airway inflammation and reversing bronchocostriction [12]. Dockhorn et al. compared the effect of intravenous and oral administration of LTRA 
montelukast on airway function. Their results showed that LTRA montelukast improved pulmonary function in chronic asthma. They also found that intravenous montelukast had a rapid onset of action and duration of action of about 24 hour in 51 patients with mild to moderate chronic asthma [16]. An early study by Hui et al. showed that the improvement in forced expiratory volume in one second (FEV1) was apparent even in those patients treated with inhaled corticosteroids [5].

While the role of antileukotrienes in the treatment of chronic asthma has been established by many trials, there are few studies of the efficacy of these drugs in acute asthma.

Leukotriene pathways are activated in acute asthma, as shown by elevations in urinary leukotriene excretion [4]. Given the increased production of LTs during an acute asthma exacerbation, it seems logical that antileukotrienes might be particularly effective in this disease. A small number of studies have now been performed to determine if two LTRAs, montelukast and zafirlukast, are effective in the treatment acute asthma. Findings of these studies are summarized in Table I.

\begin{tabular}{|c|c|c|c|c|c|c|c|}
\hline \multirow{2}{*}{$\begin{array}{c}\text { Author, } \\
\text { year } \\
\text { [reference] }\end{array}$} & \multirow{2}{*}{ Antileukotriene } & \multicolumn{2}{|c|}{ Baseline } & \multicolumn{2}{|c|}{ Maximum increase } & \multirow{2}{*}{$\begin{array}{l}\text { Discharge } \\
\text { from the ED }\end{array}$} & \multirow{2}{*}{$\begin{array}{l}\text { Reduction in } \\
\text { need for other } \\
\text { medication }\end{array}$} \\
\hline & & FEV1 & PEFR & $\begin{array}{l}\text { FEV1(\%) } \\
\text { vs. placebo }\end{array}$ & PEFR (\%) & & \\
\hline $\begin{array}{l}\text { Camargo, } \\
2003 \text { [17] }\end{array}$ & $\begin{array}{l}\text { Montelukast } \\
\text { pooled } \\
\text { (7 or } 14 \text { mg iv) }\end{array}$ & $\begin{array}{l}44,8 \pm \\
15.7 \%\end{array}$ & & $\begin{array}{c}14.8 \% \text { vs. } \\
3.6 \%\end{array}$ & & $\begin{array}{l}\text { Reduced tre- } \\
\text { atment failures } \\
\text { vs. placebo } \\
(11.1 \% \text { vs. } \\
18.2 \%)\end{array}$ & \\
\hline $\begin{array}{l}\text { Camargo, } \\
2010 \text { [18] }\end{array}$ & $\begin{array}{l}\text { Montelukast } \\
7 \mathrm{mg} \text { iv) }\end{array}$ & $\begin{array}{l}36.7 \pm \\
14.7 \%\end{array}$ & & $\begin{array}{c}\Delta \text { FEV1 } \\
(0-60) 21,4 \% \\
\text { vs. } 13,0 \%\end{array}$ & & $\begin{array}{l}\text { No significant } \\
\text { vs. placebo }\end{array}$ & \\
\hline \multirow[t]{2}{*}{$\begin{array}{l}\text { Silverman, } \\
2004 \text { [19] }\end{array}$} & $\begin{array}{l}\text { Zafirlukast } \\
160 \mathrm{mg}\end{array}$ & $\begin{array}{l}38.0 \pm \\
13.8 \%\end{array}$ & & $\begin{array}{l}\text { At } 90 \text { min } \\
\text { FEV1 in Z160 } \\
\text { were } 64 \% \\
\text { predicted vs. } \\
61 \% \text { predicted } \\
\text { in placebo }\end{array}$ & & $\begin{array}{l}\text { Reduced the } \\
\text { absolute ratio } \\
\text { extended care } \\
\text { by } 5.1 \%\end{array}$ & \\
\hline & $\begin{array}{l}\text { Zafirlukast } \\
20 \mathrm{mg} \text { once } \\
\text { daily in ED } \\
\text { and bid after } \\
\text { discharge }\end{array}$ & $\begin{array}{l}35.7 \pm \\
13.4 \%\end{array}$ & & $\begin{array}{l}\text { No significant } \\
\text { vs. placebo }\end{array}$ & & $\begin{array}{l}\text { No significantly } \\
\text { reduced the } \\
\text { absolute ratio } \\
\text { extended care } \\
\text { vs. placebo } \\
\text { Reduced the } \\
\text { absolute ratio of } \\
\text { relapse (after } 28 \\
\text { days) by } 5.3 \% \\
\text { vs. placebo }\end{array}$ & \\
\hline $\begin{array}{l}\text { Cylly, } 2003 \\
\text { [20] }\end{array}$ & $\begin{array}{l}\text { Montelukast } \\
10 \mathrm{mg}\end{array}$ & $\begin{array}{l}55.4 \pm \\
13.9 \%\end{array}$ & $\begin{array}{c}194,7 \pm \\
40.5 \mathrm{I} / \mathrm{min}\end{array}$ & & $\begin{array}{l}\text { No significant in } \\
\text { montelukast + } \\
\text { prednisone vs. } \\
\text { prednisone alone } \\
42 \text { vs. } 39.9 \%\end{array}$ & & $\begin{array}{l}\text { Reduced in } \\
\text { montelukast } \\
+ \text { prednisone } \\
\text { vs. prednisone } \\
\text { alone }\end{array}$ \\
\hline $\begin{array}{l}\text { Naqvi, } \\
2011 \text { [21] }\end{array}$ & $\begin{array}{l}\text { Montelukast } \\
10 \mathrm{mg}\end{array}$ & & $\begin{array}{c}178.87 \pm \\
27.62 \mathrm{l} / \mathrm{min}\end{array}$ & & $\begin{array}{l}194,46 \pm \\
33,46 \mathrm{I} / \mathrm{min} \\
(p=0.05)\end{array}$ & & \\
\hline
\end{tabular}

Table I. Clinical studies on montelukast and zafirlukast in acute asthma $E D=$ emergency department 


\section{Clinical studies}

In 2003 Camargo et al. in a randomized, double blind, parallel-group study in 201 adults with moderate to severe asthma (FEV1 $\leq 70 \%$ of the predicted) evaluated the response to intravenous montelukast (7 $\mathrm{mg}$ or $14 \mathrm{mg}$ ) as adjunctive therapy for acute asthma [17]. Primary endpoint of the study was the average percentage change in FEV1 from preallocation baseline at 20 minutes after study medication infusion. There was no difference in treatment effect between the groups receiving montelukast 7 or $14 \mathrm{mg}$. Compared with the group receiving standard therapy plus placebo, a significant improvement in FEV1 was observed among patients receiving standard therapy plus intravenous montelukast and this benefit was maintained for at least 2 hours. The mean percentage at 20 minutes was $14.8 \%$ versus $3.6 \%$ for the pooled montelukast and placebo treatment groups respectively. These values were $19.5 \%$ and $5.2 \%$ respectively, over the first 60 minutes [17].

In another study Camargo et al. evaluated the efficacy of intravenous montelukast as adjunctive therapy for acute asthma [18]. A total of 583 adults with acute asthma with FEV $1 \leq 50 \%$ predicted were randomly allocated to intravenous montelukast $7 \mathrm{mg}(\mathrm{n}=291)$ or placebo $(\mathrm{n}=292)$ in addition to standard care. The primary efficacy endpoint was the time-weighted average change in FEV1 during 60 minutes after drug administration. The median time-weighted percent change in FEV1 from preallocation baseline during the first 60 minutes after administration were $21.4 \%$ and $13.0 \%$ in the montelukast group and placebo group respectively. The percentage of patients with treatment failure was slightly lower in the montelukast group $(26,8 \%)$ than in the placebo one $(29,9 \%)$, but this difference was not statistically significant (OR $=0.92 ; 95 \%$ CI 0.63-1.34) [18].

Silverman et al., in a randomized, double-blind, multicenter study, evaluated the adding of therapy with zafirlukast to standardized care for patients with acute asthma in the Emergency Department (ED). A total of 641 patients presenting to the ED with acute asthma were randomized to receive either single-dose zafirlukast $160 \mathrm{mg}$, zafirlukast $20 \mathrm{mg}$, or placebo. Patients who were discharged from ED after $4 \mathrm{~h}$ continued outpatient therapy over a 28-day period and received either zafirlukast $20 \mathrm{mg}$ bid or placebo in addition to prednisone. The primary endpoint was the effect of zafirlukast on relapse after ED discharge. Other assestements were the rate of extended care (ED stay $>4 \mathrm{~h}$ or hospitalization) and FEV1. At the end of the ED period, $14 \%$ of all patients required extend care as follows: $9.9 \%$ treated with zafirlukast $160 \mathrm{mg}, 16.5 \%$ treated with zafirlukast $20 \mathrm{mg}$, and $15 \%$ treated with placebo. Compared with placebo, zafirlukast $160 \mathrm{mg}$ reduced the absolute rate of extended care by $5.1 \%(\mathrm{p}=0.052)$. Treatment with zafirlukast $160 \mathrm{mg}$ (but not with zafirlukast $20 \mathrm{mg}$ ) showed a stastistically significant effect, compared with placebo, in improving FEV1 at 90 minutes $(\mathrm{p}=0.02)$ and at 210 minutes $(\mathrm{p}=$ 0.04). Compared with placebo, treatment with zafirlukast $20 \mathrm{mg}$ bid reduced the absolute rate of relapse by $5.3 \%$ and, among patients who relapsed, the hospitalization rate was $6.2 \%$ for zafirlukast treatedpatients and $10.3 \%$ for placebo-treated patients [19].

Cylly et al. compared the effects on peak expiratory flow rate (PEFR) of oral montelukast added to intravenous steroid, intravenous steroid alone and placebo during the 24 hours following administration [20]. Secondary endpoints were Borg dyspnoea score and use of rescue medication. Seventy asthmatic patients $(\mathrm{FEV} 1=40-80 \%$ predicted $)$ were enrolled and randomized to receive montelukast $(10 \mathrm{mg})$ plus intravenous prednisolone $(1 \mathrm{mg} / \mathrm{ml})$, intravenous prednisolone alone $(1 \mathrm{mg} / \mathrm{kg}$ ) or placebo. Compared with placebo, the montelukast + prednisolone group and the prednisolone alone group had significant percentage change from baseline in PEFR in the entire 24 hours period $(10.3,42,39.9 \%)$ but the difference in PEFR between montelukast plus prednisolone and prednisolone alone did not reach statistical significance. Furthermore, montelukast plus prednisolone group require less inhaled shortacting $\beta_{2}$-agonist than other two groups [20].

Naqvi et al. conducted a comparative prospective study in 100 adult asthmatic patients randomized in two groups [21]. Group A was considered as control and was treated with conventional therapy (oxygen, short-acting $\beta_{2}$-agonists, corticosteroids and methylxantine). In group $\mathrm{B}$, along with conven- 
tional therapy, montelukast $10 \mathrm{mg}$ was added on daily basis. All the parameters of the study were recorded at the time of admission then after $24 \mathrm{~h}, 48, \mathrm{~h}, 72 \mathrm{~h}$, first week, second week and fourth week respectively. In group $B, P E F R$ after $48 \mathrm{~h}$ was significantly improved $(p=0.05)$ compared with group A. In comparation of force expiratory volume \% (FEV1 predicted) between group A and group B, after 24 $\mathrm{h}$ significant change was noticed in group B ( $\mathrm{p}=0.05)$, but, after $48 \mathrm{~h}$, there was no significant different noticed in both groups $(\mathrm{p}=0.07)$ [21].

\section{Conclusions}

The role of antileukotrienes in the treatment of acute asthma is still unknown. In a previous review Kluitert and Watson underlined that there are few studies evaluating the effect of an LTRA in acute asthma and these studies are limited by the lack of clinically relevant outcomes such as hospitalization and relapse rates. However, the study on zafirlukast, in which patients were treated both acutely and on discharge from the ED, demonstrated a reduction in the number of patients requiring a longer stay in $\mathrm{ED}$ and/or hospitalization, a lower relapse rate and greater improvement in lung function [19,22]. In their randomized, double-blind, placebo-controlled study, published in 2010, Camargo et al. found that intravenous montelukast, when added to standard therapy, provided significant, rapid (onset of action at 10 minutes), and sustained (throughout the 2 hours) benefit in acute asthma, as indicated by relief of airway obstruction [18]. Another study showed that adding oral montelukast to intravenous steroid caused significant change from baseline in PEFR in the entire 24 hours and required less inhaled short-acting $\beta_{2}$-agonist as a rescue medication [20]. In all studies antileukotrienes were found to be generally safe and well tolerated in acute asthma. In summary, although only few studies have been performed yet, there are data suggesting that potential advantages of prescribing antileukotrienes as

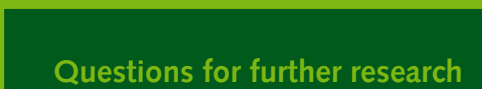

There are still few studies on the role of antileukotrienes in the treatment of acute asthma. Additional studies with clinically relevant outcomes (i.e., hospitalization and relapse rate) should be performed in order to determine their potential additive benefit to current acute asthma treatment. adjunctive therapy in acute asthma. Oral or intravenous LTRAs have an additive benefit in terms of early improvement in lung function (FEV1 and PEFR), reduce the necessity of extended care in ED, relapses rate after discharge and rescue medication with short acting $\beta_{2}-$ agonist. However, additional studies are necessary to determine the potential additive benefit of antileukotrienes to current acute asthma treatment.

\section{The review in brief}

Clinical question Defining the role of antileukotrienes in acute asthma

Type of review Narrative

Search of the Medline search for English-language articles using the following keywords: asthma, leukotrienes, literature cysteinil-leukotrienes, airways inflammation

Conclusions Data suggest potential advantages of antileukotrienes prescription as adjunctive therapy in acute asthma. Oral or intravenous LTRAs have an additive benefit in terms of early improvement in lung function (FEV1 and PEFR), reduce the necessity of extended care in ED, relapses rate after discharge and rescue medication with short acting $\beta_{2}$-agonist

Limitations Only few clinical trials have been performed, thus this review is based on a limited number of studies 


\section{References}

1. Global Strategy for Asthma Management and Prevention, Global Initiative for Asthma (GINA) 2010. Available at: http://www.ginasthma.org (latest access March 2012). The Italian translation is available at: http://www.ginasthma.it

2. National Institutes of Health, National Heart, Lung and Blood Institute National Asthma Education and Prevention Program. Expert Panel Report 3: Guidelines for the Diagnosis and Management of Asthma 2007; Publ. No. 08-4051

3. BTS, British Thoracic Society Scottish Intercollegiate Guidelines Network. British Guideline on the Management of Asthma. Thorax 2008; 63(Suppl IV): IV1-IV121

4. Sampson AP, Green CP, Spencer DG, et al. Leukotrienes in the blood and urine of children with acute asthma. Ann NY Acad Sci 1991; 629: 437-9

5. Hui KP, Barnes NC. Lung function improvement in asthma with a cysteinil-leukotriene receptor antagonist. Lancet 1991; 337: 1062-3

6. Foresi A, Paggiaro P. Inhaled corticosteroids and leukotriene modifiers in the acute treatment of asthma exacerbations. Curr Opin Pulm Med 2003; 9: 52-6

7. Peters-Golden M, Henderson WR. Leukotrienes. N Engl J Med 2007; 357: 1841-54

8. Montuschi P, Sala A, Dalhén SE, et al. Pharmacological modulation of the leukotriene pathway in allergic airway disease. Drug Discov Today 2007; 12: 404-12

9. Lynch KR, O'Neill GP, Liu Q, et al. Characterization of the human cysteinil leukotriene Cys-LT1 receptor. Nature 1999; 399: 789-93

10. Sampson AP, Pizzichini E, Bisgaard H. Effect of cysteinil leukotrienes and leukotriene receptor antagonists on markers of inflammation. J Allergy Clin Immunol 2003, 111: S49-59

11. Dalhén SE. Treatment of asthma with antileukotrienes: first line or last resort therapy? Eur J Pharmacol 2006: 533: 40-56

12. Montuschi P. Role of leukotrienes and leukotriene modifiers in asthma. Pharmaceutical 2010; 3: 1792-811; doi:10.3390/ph3061792

13. Urso DL. Treatment for acute asthma in the Emergency Department: practical aspects. Eur Rev Med Pharmacol Sci 2010; 14: 209-14

14. Strauss L, Hejal R, Galan G, et al. Observations on the effects of aerosolized albuterol in acute asthma. Am J Respir Crit Care Med 1997; 155: 454-8

15. Rowe BH, Spooner C, Ducharme FM, et al. Early emergency department treatment of acute asthma with systemic corticosteroids. Cochrane Database Syst Rev 2001; (1): CD002178

16. Dockhorn RJ, Baurngartner RA, Leff JA, et al. Comparation of the effects of intravenous and oral montelukast on airways function: a double blind, placebo controller, three period, crossover study in asthmatic patients. Thorax 2000; 55: 260-5

17. Camargo CA Jr, Smithline HA, Malice M, et al. A randomized controlled trial of intravenous montelukast in acute asthma. Am J Respir Crit Care Med 2003; 167: 528-33

18. Camargo CA Jr, Gurner DM, Smithline HA, et al. A randomized placebo-controlled study of intravenous montelukast for the treatment of acute asthma. J Allergy Clin Immunol 2010; 125: 374-80; doi:10.1016/j.jaci.2009.11.015

19. Silverman RA, Nowak RM, Korenblat PE, et al. Zafirlukast treatment for acute asthma. Chest 2004; 126: 1480-9; doi: 10.1378/chest.126.5.1480

20. Cylly A, Kara A, Ozdemir A, et al. Effects of oral montelukast on airway function in acute asthma. Respir Med 2003; 97: 533-6

21. Naqvi SH, Rukh M, Siddiqui FA et al. Role of leukotriene antagonist in acute severe attack of bronchial asthma in comparation with conventional therapy. Pak J Parmacol 2011; 28: 13-21

22. Kluitert LME, Watson D. Antileukotrienes as adjunctive therapy in acute asthma. Drug 2007; 67: 1665-70 